\title{
A design of experiments to assess phosphorous removal and crystal properties in struvite precipitation of source separated urine using different Mg sources
}

\author{
Sónia G. Barbosa ${ }^{\mathrm{a}}$, Luciana Peixoto ${ }^{\mathrm{a}}$, Brendo Meulman ${ }^{\mathrm{b}}$, Maria Madalena Alves ${ }^{\mathrm{a}}$, Maria Alcina Pereira ${ }^{\mathrm{a}, *}$ \\ ${ }^{a}$ CEB - Centre of Biological Engineering, University of Minho, Campus de Gualtar, 4710-057 Braga, Portugal \\ ${ }^{\mathrm{b}}$ DeSaH B.V., Pieter Zeemanstraat 6, 8606JR Sneek, Netherlands
}

\section{H I G H L I G H T S}

- Only the variable Mg:P molar ratio had a significant influence on $P$ recovery.

- $99 \%$ of $\mathrm{P}$ was recovered with $\mathrm{MgO}$ as $\mathrm{Mg}^{2+}$ source, 2:1 molar ratio and $30 \mathrm{rpm}$.

- Struvite crystals with $50-100 \mu \mathrm{m}$ size were obtained.

- XRD patterns were coherent with the standard model for struvite crystals.

- Only the variable stirring speed had a significant effect on crystal size.

\section{A R T I C L E I N F O}

\section{Article history:}

Received 12 December 2015

Received in revised form 14 February 2016

Accepted 30 March 2016

Available online 6 April 2016

\section{Keywords:}

Human urine

Phosphorus recovery

Magnesium sources

Stirring speed

Struvite crystal size
G R A P H I C A L A B S T R A C T

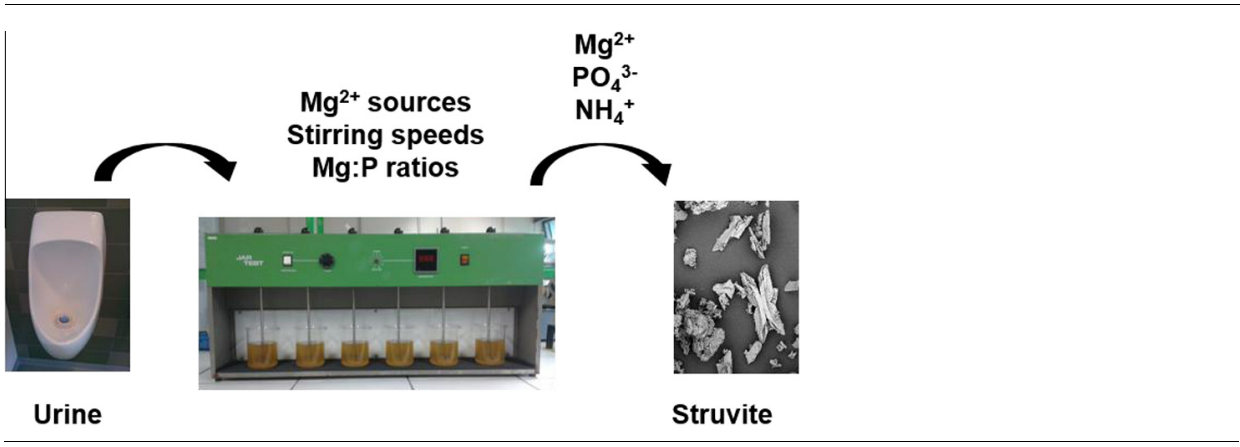

A B S T R A C T

Phosphorus recycling and recovery has received special attention due to its non-replaceable and nonrenewability. Phosphorus recovery from human urine in the form of struvite crystals is a potential alternative source. In this work, the efficiency of struvite precipitation from source separated human urine and struvite crystals size were analyzed using three different $\mathrm{Mg}^{2+}$ sources $\left(\mathrm{MgCl}_{2}, \mathrm{Mg}(\mathrm{OH})_{2}\right.$ and $\mathrm{MgO})$, individually evaluated using a statistical design of experiments to assess the combined effect of $\mathrm{Mg}^{2+}:$ P molar ratio $(1: 1,1.5: 1$ and $2: 1)$ and stirring speed $(30,45$ and $60 \mathrm{rpm})$. Formation of struvite crystals was confirmed by X-ray diffraction (XRD) and scanning electron microscopy (SEM) with an energy dispersive spectrometer (EDS). Using the optimal conditions determined, $\mathrm{MgO}$ as $\mathrm{Mg}^{2+}$ source at 2:1 molar ratio and a stirring speed of $30 \mathrm{rpm}, 99 \%$ of $\mathrm{P}$ was recovered as struvite crystals with a size of 50-100 $\mu \mathrm{m}$.

(c) 2016 Elsevier B.V. All rights reserved.

\section{Introduction}

Phosphorus (P) is an essential nutrient for all types of life. Phosphate rock is the major source of P predominantly originating from China, United States, Morocco and Russia [1]. An annual increase in phosphorus consumption has been observed and its

\footnotetext{
* Corresponding author.

E-mail address: alcina@deb.uminho.pt (M.A. Pereira).
}

overall future demand is anticipated to rise due to the increase in population growth and per capita phosphorus demand. Depending of the different assumptions, a vast range of global phosphate depletion estimates indicating different peak years have been reported [2]. In general, the different scenarios described depend of the assumptions about demand, supply, and the depletion model employed. Cordell et al. [3] estimated phosphorus to peak by 2035 based on 2009 USGS reserve data, however the International Fertilizer Development Center (IFDC) re-estimated global phosphate rock reserves and the peak shifts to 2051-2092 [2]. 
Therefore, its efficient use, recovery and recycling methods are priorities to face the needs of this non-renewable and nonreplaceable nutrient.

Crystallization processes have the potential to recover $\mathrm{P}$ in the form of useful products such as struvite $\left(\mathrm{MgNH}_{4} \mathrm{PO}_{4} \cdot 6 \mathrm{H}_{2} \mathrm{O}\right)$, hydroxyapatite $\left(\mathrm{Ca}_{10}\left(\mathrm{PO}_{4}\right)_{6}(\mathrm{OH})_{2}\right)$ and calcium phosphate $\left(\mathrm{Ca}_{3}(-\right.$ $\left.\mathrm{PO}_{4}\right)_{2}$ ) $[3,4]$. Struvite presents some advantages compared to the other crystal forms: (i) nutrients are released at a slower rate compared to other fertilizers, (ii) the impurities in the recovered struvite are two or three orders of magnitude lower than the commercial phosphate fertilizers, and (iii) the essential nutrients $\left(\mathrm{P}\right.$, nitrogen $(\mathrm{N})$ and magnesium $\left.\left(\mathrm{Mg}^{2+}\right)\right)$ are simultaneously on the same crystal [4]. Research focused on P recovery through struvite precipitation has received attention in the last years and, specifically, P recovery from urine has been reported using several processes such as hybrid anion exchange resins [5], single chamber microbial fuel cells [6] or electrolytic magnesium dosage [7].

Human urine contributes with only $1 \%$ to the volume of municipal wastewater, however contributes to about up to $50 \%$ of the $\mathrm{P}$ load [8]. On average, urine contains $1 \mathrm{~g} \mathrm{~L}^{-1}$ of $\mathrm{P}, 9 \mathrm{~g} \mathrm{~L}^{-1}$ of $\mathrm{N}$ and $10 \mathrm{~g} \mathrm{~L}^{-1}$ of chemical oxygen demand (COD) [9]. Due to these high concentrations, human urine can be a valuable resource for $\mathrm{N}, \mathrm{P}$ and energy recovery [10].

$P$ recovery from urine has received a lot of attention with regard to struvite production in simply operated reactors that only requires an $\mathrm{Mg}$ source. Struvite precipitation from sourceseparated urine have been reported mainly in developing and emerging countries, where P levels in soils is frequently below optimal and consequently more fertilizers are required due to the rapidly increase of food production $[2,11]$. Reactors manufactured to produce struvite from urine in decentralized treatment systems have been used for P recover on a small scale in developing countries [12-14]. In developed countries $P$ recovery from urine have been also reported in decentralized settings after which the treated liquid would be discharged via existing sewers [15]. Several technologies have been proposed for P recovery from urine [7,16-18].

$P$ recovery by precipitation from separated human urine is possible if NoMix toilets and waterless urinals are used. NoMix technology is well accepted; around $80 \%$ of users liked the idea, $75-$ $85 \%$ were satisfied with design, hygiene, smell, and seating comfort of NoMix toilets, $85 \%$ regarded urine-fertilizers as good idea and $70 \%$ would purchase such food [19].

$P$ recovery from urine occurs in two successive steps namely spontaneous and non-spontaneous precipitation [18]. During storage of urine, urea is completely hydrolyzed into carbon dioxide and ammonia (Eq. (1)) [20]. Ammonium $\left(\mathrm{NH}_{4}^{+}\right)$in equilibrium reacts with the phosphate $\left(\mathrm{PO}_{4}^{3-}\right)$, and $\mathrm{Mg}^{2+}$ ions present in the urine, and struvite crystallization occurs spontaneously (Eq. (2)) [21].

$\left(\mathrm{NH}_{2}\right)_{2} \mathrm{CO}+\mathrm{H}_{2} \mathrm{O} \rightarrow \mathrm{CO}_{2}+2 \mathrm{NH}_{3}$

$\mathrm{Mg}^{2+}+\mathrm{NH}_{4}^{+}+\mathrm{PO}_{4}^{3-} \cdot 6 \mathrm{H}_{2} \mathrm{O} \rightarrow \mathrm{MgNH}_{4} \mathrm{PO}_{4} \cdot 6 \mathrm{H}_{2} \mathrm{O}$

This precipitation is limited by the availability of $\mathrm{Mg}^{2+}$ and the addition of a $\mathrm{Mg}^{2+}$ source, results in an effective P recovery [17] in a process called non-spontaneous struvite precipitation. The most common precipitants are magnesium oxide (MgO) [16], magnesium chloride $\left(\mathrm{MgCl}_{2}\right)$ [22] and magnesium hydroxide $\left(\mathrm{Mg}(\mathrm{OH})_{2}\right)$ [23]. Due to its basic character $\mathrm{MgO}$ and $\mathrm{Mg}(\mathrm{OH})_{2}$, can serve a dual purpose of $\mathrm{Mg}$ addition and $\mathrm{pH}$ increase. On the other hand, $\mathrm{MgCl}_{2}$ has been reported as a more effective for $\mathrm{P}$ recovery reducing the reaction time due to its greater solubility [24].

Several physico-chemical parameters influence the $P$ recovery efficiency, such as, pH [4], stirring speed [25], temperature [26],
Mg:P molar ratio [27], presence of seeding materials [28] and presence of foreign ions [20].

In this work, a statistical design of experiments is applied to optimize the struvite precipitation from source separated human urine. The combined effect of the stirring speed, the stirring time, the sedimentation time and the Mg:P ratio is evaluated on the $P$ removal efficiency and struvite crystal properties. The power of the design of experiments that decreases the number of experiments intercorrelated, maintaining the security of the results, is herein demonstrated on the assessment of fundamental parameters affecting the complex struvite precipitation process from human urine.

\section{Materials and methods}

\subsection{Design of experiments and statistical analysis}

In order to understand which factors affect $\mathrm{P}$ removal and to optimize $P$ recovery efficiency $\left(P_{\text {removal }}\right.$ ), several preliminary batch assays were performed. Three different stirring times $(10,35$ and $60 \mathrm{~min}$ ), three stirring speeds (60, 90 and $120 \mathrm{rpm})$, three $\mathrm{Mg}: \mathrm{P}$ molar ratios $(1: 1,2: 1$ and $3: 1)$ and three sedimentation times (30, 45 and $60 \mathrm{~min}$ ) were investigated for each $\mathrm{Mg}^{2+}$ source ( $\mathrm{MgO}, \mathrm{Mg}(\mathrm{OH})_{2}$ and $\mathrm{MgCl}_{2}$ ) tested. The Design-Expert ${ }^{\circledR}$ software package (Stat-Ease Inc., Minneapolis, USA) was used for planning the assays and a set of 52 experiments were performed. A central composite face-centred design (CCF), using response surface methodology, was carried out according to a three-level factorial design, containing a central point $(\mathrm{CP})$.

The results obtained in the preliminary assays were used to refine the test and plan a new set of experiments, with the same software, correlating only two variables at high (+1) and low $(-1)$ levels. According to the results obtained by previous factorial design experiment, (A) Mg:P molar ratio (1:1, 1.5:1 and 2:1) and (B) stirring speed (30, 45 and $60 \mathrm{rpm})$ were the parameters studied at three levels with two repetitions (duplicates) with a central point tested in triplicate ( 3 central points) (Table 1 ). Fixed parameters were stirring time ( $10 \mathrm{~min}$ ) and sedimentation time (30 min). A set of 19 experiments were carried out for each $\mathrm{Mg}^{2+}$ source.

The performance of all the models suggested was assessed based in different parameters. The correlation coefficient $\left(R^{2}\right)$ measures the fraction of the total variability in the response. $R^{2}$ value closer to unity indicated that the standard deviation was reduced

Table 1

Experimental design matrix with operating conditions for $\mathrm{P}$ recovery efficiency assays.

\begin{tabular}{lll}
\hline Run & Mg:P ratio & Stirring speed $\mathrm{rpm}$ \\
\hline 1 & 1.0 & 30 \\
2 & 1.5 & 60 \\
3 & 1.5 & 30 \\
4 & 1.5 & 60 \\
5 & 1.0 & 60 \\
6 & 1.5 & 45 \\
7 & 1.0 & 30 \\
8 & 1.0 & 45 \\
9 & 1.0 & 60 \\
10 & 2.0 & 60 \\
11 & 2.0 & 30 \\
12 & 1.5 & 45 \\
13 & 2.0 & 45 \\
14 & 1.5 & 45 \\
15 & 2.0 & 60 \\
16 & 2.0 & 30 \\
17 & 2.0 & 45 \\
18 & 1.5 & 30 \\
19 & 1.0 & 45 \\
\hline
\end{tabular}


and the predicted results were in good agreement with experimental data. Coefficient of variation (CV) is a measure of the amount of variation as a percentage of the total mean. A CV less than $10 \%$ represents means that the model is reproducible [29]. Adequate precision (AP) is a measure of the difference in predicted response relative to its associated error (a signal to noise ratio). AP can be certified with a signal greater than 4 [29].

\subsection{Phosphorus removal by struvite precipitation}

Urine from different individuals, males and females with a broad age range between 20 and 50 years old, was collected at different times in different days, mixed and analyzed. The P and COD concentrations were determined using Hach-Lange cuvette tests (LCK 350 and LCK 338, respectively) and total Kjeldahl nitrogen (TKN) and ammonium $\left(\mathrm{N}-\mathrm{NH}_{4}^{+}\right.$) by using the Kjeldahl method according to Standard Methods [30]. Electrical conductivity and $\mathrm{pH}$ were measured with portable conductivity meter (Multi 340i, WTW, Germany) and a portable pH meter (HI 83141, Hanna, Italy), respectively.

To determine the time course of spontaneous precipitation of struvite from real undiluted human urine, a first experiment was performed. Fresh collected urine was stored at room temperature in a plastic container during several days. Samples were taken daily to monitor changes in $\mathrm{pH}$ and to measure TKN, N-NH $\mathrm{N}_{4}^{+}, \mathrm{COD}$ and $\mathrm{P}$ concentrations. The collected samples were preserved with $5 \% \mathrm{H}_{2} \mathrm{SO}_{4}(1 \mathrm{M})$ and stored at $4{ }^{\circ} \mathrm{C}$ until analysis. Following the spontaneous struvite precipitation, the supernatant was decanted and several $\mathrm{Mg}^{2+}$ sources were then added to induce additional struvite precipitation. The use of different $\mathrm{Mg}^{2+}$ sources was investigated in $600 \mathrm{~mL}$ beakers (work volume of $300 \mathrm{~mL}$ ) in a jar-test apparatus (AMF/60, Vittadini, Italy) at room temperature, adding $\mathrm{MgO}, \mathrm{Mg}(\mathrm{OH})_{2}$ and $\mathrm{MgCl}_{2}$ at different $\mathrm{Mg}$ :P molar ratios. $\mathrm{Mg}^{2+}$ dose added was calculated based on initial $\mathrm{P}$ concentration and the initial $\mathrm{pH}$ of the urine was kept at the designed level (8.5) [31]. After $\mathrm{Mg}^{2+}$ addition, the solution was stirred for $10 \mathrm{~min}$ and was rested to sediment for $30 \mathrm{~min}$. P removal efficiency was calculated after determination of initial and final $\mathrm{P}$ concentration.

\subsection{Precipitate analysis - crystal size, XRD and SEM-EDS}

The different conditions applied on struvite precipitation influenced the size of the crystals obtained. Therefore, the same CCF experimental design mentioned in Section 2.1 was used to assess the effect of Mg:P ratio and stirring speed on particle size. Thereby, $1 \mathrm{~mL}$ of struvite precipitated after non-spontaneous precipitation from each experiment were collected for a Petri dish to microscopic analysis and particle size assessment. Samples were stored at $4{ }^{\circ} \mathrm{C}$ until observation. Precipitated crystals were observed in a Nikon inverted microscope Diaphot 300 , at $100 \times$ total magnification, coupled with a Sony CCD video camera and the software IMAGE-PRO. Images were acquired in the upper, middle and bottom of the sample with controlled distances, in order to ensure the representativeness of the sample. The longitudinal size of the precipitated crystals was measured by Image J, image edition program. Around 20 images were obtained per sample and an average of 876 crystals were analyzed per assay.

Samples from the precipitates were also collected and dried at $45^{\circ} \mathrm{C}$ in order to characterize the crystals by X-ray diffraction (XRD) and scanning electron microscopy (SEM) with an energy dispersive spectrometer (EDS). XRD allows matching the intensity and position of the peaks in the diffractogram of each sample and a standard model diffractogram for struvite crystals. The XRD measurements were performed on a Phillips X-ray model PW 1710 BASED powder diffractometer equipped with $\mathrm{CuK} \alpha$ monochromatic radiation. SEM-EDS allows to identify the crystals precipi- tated by comparing the chemical composition obtained in an energy dispersive spectrograph with a standard spectra of pure struvite. Surface morphological and compositional analyses were carried out using a SEM FEI Nova 200 with integrated EDS analysis (EDAX, Pegasus X4M).

\section{Results and discussion}

\subsection{Phosphorus removal by struvite precipitation}

Fresh urine was stored and $\mathrm{P}$ concentration and $\mathrm{pH}$ were followed over time, in order to obtain the time course of struvite spontaneous precipitation. The $\mathrm{pH}$ increased from 5.9 to 8.6 as a result of urea hydrolysis, leading to a $\mathrm{PO}_{4}^{3-}$ concentration decrease as a result of the reaction with $\mathrm{NH}_{4}^{+}$and $\mathrm{Mg}^{2+}$ ions (Table 2). Liu et al. [31] reported that during urea hydrolysis, the $\mathrm{pH}$ increased and stabilized at around 9.0. As a consequence of $\mathrm{pH}$ increase, it was observed that after 6 days of urine storage, around $31 \%$ of $\mathrm{P}$ was recovered through spontaneous struvite precipitation. Similar results were reported by Etter et al. [13] with about $30 \%$ of the P removed due to spontaneous precipitation as calcium phosphate and struvite in undiluted urine. Liu and co-workers [32] demonstrated that after 5 days of urine storage almost 38\% of $\mathrm{P}$ was recovered, after which only a minimum variation was observed. Since struvite precipitation is limited by availability of magnesium, addition of $\mathrm{Mg}^{2+}$ source will induce additional precipitation. In fact $\mathrm{Mg}^{2+}$ was depleted by $90 \%$ in the spontaneous precipitation process.

Preliminary batch assays were performed in order to understand which factors affect $P$ removal in non-spontaneous precipitation (Fig. S1, Supplementary Material). From these preliminary assays, it could be concluded that the $\mathrm{Mg}: \mathrm{P}$ ratio and the stirring speed were the most relevant parameters. Thus, a process analysis CCF was performed with the purpose of correlate these two variables: (A) stirring speed (30, 45 and $60 \mathrm{rpm}$ ) and (B) Mg:P molar ratios $(1: 1 ; 1.5: 1$ and $2: 1)$ in order to optimize the $P$ recovery efficiency. The effect of each variable was described by modulation according to a two-factor, three-level central composite design with response surface methodology (RSM). Based on preliminary experiments, the reaction and the sedimentation times, of 10 and $30 \mathrm{~min}$, were respectively established. In each run, $\mathrm{Mg}^{2+}$ dose added was calculated based on the initial phosphorus concentration. The initial $\mathrm{pH}$ was kept at the designed level (8.5) [31] by $\mathrm{H}_{2} \mathrm{SO}_{4}(1 \mathrm{M})$ addition.

Fig. 1 shows the effect of the stirring speed and Mg:P molar ratio on $\mathrm{P}$ recovery efficiency using three different $\mathrm{Mg}^{2+}$ sources. In order to access the significance of each variable in the selected model, an analysis of variance (ANOVA) was applied. The value of statistical significance was set at $p<0.05$, which means that the model terms are significant for values of $p$ lower than 0.05 .

The highest $P$ recovery efficiencies, ranging from $90 \%$ to $99 \%$, depending on the operating conditions applied, were obtained using $\mathrm{MgO}$ as $\mathrm{Mg}^{2+}$ source. After the addition of $\mathrm{MgO}$ in the beakers, the $\mathrm{pH}$ increased from 8.5 to $8.7-9$ in the first $3 \mathrm{~min}$ and remained at $8.9-9.2$ during stirring time (10 $\mathrm{min})$.

Table 2

Composition of fresh and stored human urine $(n=3)$.

\begin{tabular}{llrl}
\hline & & Fresh urine & Stored urine \\
\hline $\mathrm{pH}$ & & $5.92 \pm 0.02$ & $8.59 \pm 0.01$ \\
$\mathrm{COD}$ & $\mathrm{g} \mathrm{L}^{-1}$ & $8.50 \pm 2.23$ & $9.29 \pm 0.57$ \\
$\mathrm{TKN}$ & $\mathrm{g}_{\mathrm{N}} \mathrm{L}^{-1}$ & $0.54 \pm 0.08$ & $9.18 \pm 0.36$ \\
$\mathrm{~N}-\mathrm{NH}_{4}^{+}$ & $\mathrm{g}_{\mathrm{N}} \mathrm{L}^{-1}$ & $0.79 \pm 0.01$ & $0.55 \pm 0.00$ \\
$\mathrm{P}$ & $\mathrm{g}_{\mathrm{P}} \mathrm{L}^{-1}$ & $23.10 \pm 1.20$ & \\
Conductivity & $\mathrm{mS} \mathrm{cm}^{-1}$ & & \\
\hline
\end{tabular}




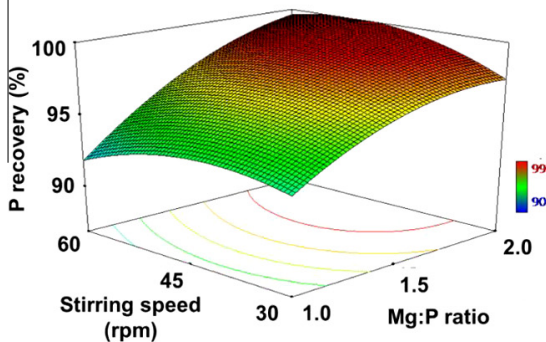

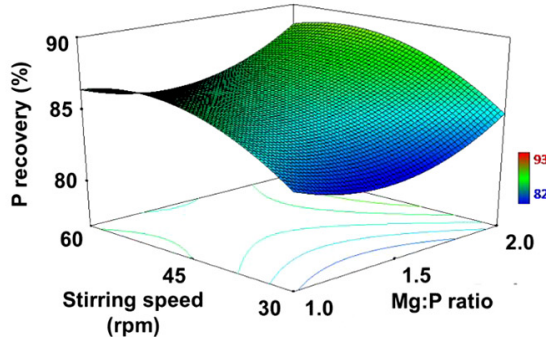

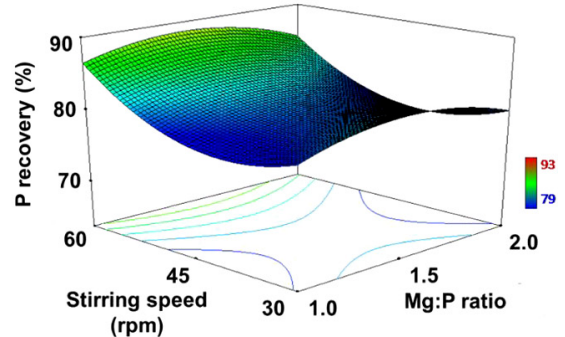

Fig. 1. Response graphs showing the effect of $\mathrm{Mg}: \mathrm{P}$ ratio and stirring speed on $\mathrm{P}$ recovery efficiencies with different $\mathrm{Mg}{ }^{2+}$ sources $(\mathrm{A}) \mathrm{MgO} ;(\mathrm{B}) \mathrm{MgCl}{ }_{2}$ and $\left.(\mathrm{C}) \mathrm{Mg}_{(\mathrm{OH}}\right)_{2}$.

The role of each variable can be described by the Eq. (3) $(F$-value $=7.12)$ where $\mathrm{P}$ is the phosphorus recovery efficiency. Only the variable $\mathrm{A}, \mathrm{Mg}: \mathrm{P}$ ratio, had a significant influence on $P$ recovery efficiency (Table 3 ). A maximum $P$ recovery of $99 \%$ was obtained in the experiment with $\mathrm{Mg}: \mathrm{P}$ ratio $=2: 1$ for the three stirring speeds studied, which was also predicted by the model $(100 \% \mathrm{P}$ recovery for $\mathrm{Mg}: \mathrm{P}$ ratio $=2: 1$ ), evidencing a clear match between model prediction and the experimental response (Fig. 1A). Capdevielle et al. [33] demonstrated that the optimal conditions for the removal of $P$ from synthetic swine wastewater were Mg:P molar ratio of 2.25:1, moderate stirring rate (between 45 and $90 \mathrm{rpm}$ ) and low temperature (below $20^{\circ} \mathrm{C}$ ).

$$
\begin{aligned}
\mathrm{P}_{\text {recovery }}(\%)= & 73.07+16.40 \mathrm{~A}+0.36 \mathrm{~B}+0.12 \mathrm{AB}-5.22 \mathrm{~A}^{2} \\
& -5.80 \mathrm{E}-3 \mathrm{~B}^{2}
\end{aligned}
$$

With $\mathrm{MgCl}_{2}$ as $\mathrm{Mg}^{2+}$ source, $\mathrm{P}$ recovery efficiency ranged from $82 \%$ to $89 \%$, depending of the conditions applied. The $\mathrm{pH}$ value decreased from 8.5 to 7 -to- 8 in the first 3 min after the addition of $\mathrm{MgCl}_{2}$. The $\mathrm{pH}$ remained at 7-7.5 during the reaction time (10 min). The model was described by the Eq. $(4)(F$-value $=4.05)$. ANOVA analysis showed that $A^{2}$ was the only significant variable for the model (Table 3 ). According to the quadratic model, the maximum $\mathrm{P}$ recovery that can be achieved for experimental parameters applied was $89 \%$ at $\mathrm{Mg}: \mathrm{P}$ ratio of $2: 1$ and a $60 \mathrm{rpm}$ (Fig. 1B). The experimental value obtained (89\%) was consistent with the predicted response and validates the model. Despite the stoichiometric Mg:P ratio of $1: 1$, studies reported a low P removal for Mg:P ratio around this value. Munch and Barr [34] reported a $P$ recovery of $94 \%$ using a $\mathrm{Mg}: \mathrm{P}$ ratio of $1: 1.3$ whereas Adnan and coworkers [35] reported a P recovery of $62 \%$ for a $\mathrm{Mg}: \mathrm{P}$ ratio of $1.2: 1$. Song et al. [27] showed that increasing Mg:P molar ratio up to 2.2:1 promotes the removal efficiency at different $\mathrm{pH}$ studied, furthermore at a low $\mathrm{pH}$ value of 8.0 the $\mathrm{P}$ removal efficiency increased significantly. Wilsenach and co-workers [16] demonstrated that with addition of $\mathrm{MgCl}_{2}$, the $\mathrm{P}$ removal was linear with

Table 3

ANOVA analysis for the effect of $\mathrm{Mg}: \mathrm{P}$ ratio and stirring speed on $\mathrm{P}$ recovery.

\begin{tabular}{llll}
\hline & \multicolumn{2}{l}{ Prob $>\mathrm{F}$} & \\
\cline { 2 - 4 } & $\mathrm{MgO}^{\mathrm{a}}$ & $\mathrm{MgCl}_{2}{ }^{\mathrm{b}}$ & $\mathrm{Mg}(\mathrm{OH})_{2}{ }^{\mathrm{c}}$ \\
\hline Model & 0.0021 & 0.0195 & 0.0061 \\
$\mathrm{~A}:$ Mg:P ratio & $0.0193(+)$ & $0.5621(-)$ & $0.6669(+)$ \\
$\mathrm{B}:$ Stirring speed & $0.1889(+)$ & $0.1007(+)$ & $0.0028(-)$ \\
$\mathrm{AB}$ & $0.2193(+)$ & $0.8607(+)$ & $0.7149(-)$ \\
$\mathrm{A}^{2}$ & $0.1781(-)$ & $0.0506(+)$ & $0.0656(-)$ \\
$\mathrm{B}^{2}$ & $0.1781(-)$ & $0.0574(-)$ & $0.0054(+)$ \\
\hline
\end{tabular}

a $\mathrm{SD}=1.92, R^{2}=0.73, R^{2}$ adj. $=0.63, \mathrm{AP}=7.44, \mathrm{CV}=1.99 \%$.

b $\mathrm{SD}=1.98, R^{2}=0.61, R^{2}$ adj. $=0.46, \mathrm{AP}=6.01, \mathrm{CV}=2.30 \%$.

c $\mathrm{SD}=1.46, R^{2}=0.67, R^{2} \mathrm{adj} .=0.51, \mathrm{AP}=5.77, \mathrm{CV}=1.80 \%$. increasing $\mathrm{Mg}$ :P ratio and with initial $\mathrm{pH}$ of 8.2, a P removal efficiency of $75 \%$ was achieved with an overdose of $\mathrm{Mg}^{2+}(\mathrm{Mg}: \mathrm{P}$ ratio $=2: 1)$

$$
\begin{aligned}
\mathrm{P}_{\text {recovery }}(\%)= & 79.41-23.31 \mathrm{~A}+0.88 \mathrm{~B}+0.02 \mathrm{AB}+8.13 \mathrm{~A}^{2} \\
& -8.74 \mathrm{E}-3 \mathrm{~B}^{2}
\end{aligned}
$$

Using $\mathrm{Mg}(\mathrm{OH})_{2}$, the experimental values of P recovery efficiency ranged from $79 \%$ to $93 \%$. After $\mathrm{Mg}(\mathrm{OH})_{2}$ addition, the $\mathrm{pH}$ at $8.5-8.7$ during $3 \mathrm{~min}$ and stabilized at these values during all the reaction (10 min). The effect of each variable on $P$ recovery was described by a quadratic model as shown in the Eq. (5) ( $F$-value $=5.52$ ). The variables that demonstrated a significant effect on $P$ recovery efficiency were $\mathrm{B}$ and $\mathrm{B}^{2}$ (Table 3 ).The optimized solution suggested by the software, consisted of Mg:P ratio of 1.5:1 and a stirring speed of $60 \mathrm{rpm}$ which correspond to $89 \%$ of $\mathrm{P}$ recovery (Fig. 1C). The maximum experimental $P$ recovery of $93 \%$ was achieved at the same conditions (Mg:P ratio of $1.5: 1$ and $60 \mathrm{rpm}$ ). Quadratic model showed clearly that mixing intensity had a significant effect on $P$ removal by struvite precipitation for the range of speeds tested. A stirring speed increase leads to $\mathrm{CO}_{2}$ liberation increasing the $\mathrm{pH}$ and therefore an increase in $\mathrm{P}$ recovery through struvite precipitation was achieved [36].

$$
\begin{aligned}
P_{\text {recovery }}(\%)= & 85.65+34.49 \mathrm{~A}-1.53 \mathrm{~B}-0.05 \mathrm{AB}-10.91 \mathrm{~A}^{2} \\
& +0.02 \mathrm{~B}^{2}
\end{aligned}
$$

\subsection{Precipitate analysis}

\subsubsection{Crystal size measurement - Image J}

Precipitation of struvite occurs in two stages: nucleation and crystal growth. These stages influence directly the particle size of crystals $[37,27]$. Nucleation is strongly dependent on the super saturation and crystals growth rate depends on the stirring speed because it is a mass transport limited process [32]. The effect of $\mathrm{Mg}$ :P ratio and stirring speed on crystal size (Fig. 2) was assessed for the same set of 19 experiments, determined by CCF experimental design (Table 1 ).

Using $\mathrm{MgO}$ as $\mathrm{Mg}^{2+}$ source, the variable that had a significant effect on crystal size was $B^{2}$ (Table 4 ). At $30 \mathrm{rpm}$, the particle size distribution showed a slightly bimodal behavior with the presence of fine particles around $50 \mu \mathrm{m}$ and larger crystals around $100 \mu \mathrm{m}$ size. Crystals around the $50 \mu \mathrm{m}$ were more frequent in the experiments with 45 and $60 \mathrm{rpm}$ (Fig. 2Aa).

Using $\mathrm{MgCl}_{2}$, the variables $\mathrm{B}$ and $\mathrm{B}^{2}$ were the leading process parameters on crystal size (Table 4 ). The most common crystal size ranged from $20 \mu \mathrm{m}$ at $30 \mathrm{rpm}$ to $40 \mu \mathrm{m}$ at $60 \mathrm{rpm}$, whereas the biggest crystals with around $70 \mu \mathrm{m}$ were obtained at $45 \mathrm{rpm}$ (Fig. 2Bb). Ariyanto and co-workers [38] studied the mechanisms of crystal formation using a di-hydrogen ammonium phosphate solution. These authors clearly showed that the crystal size was 


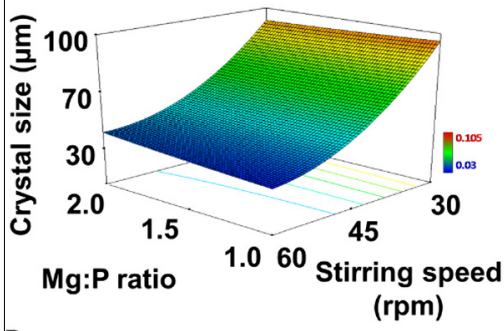

B

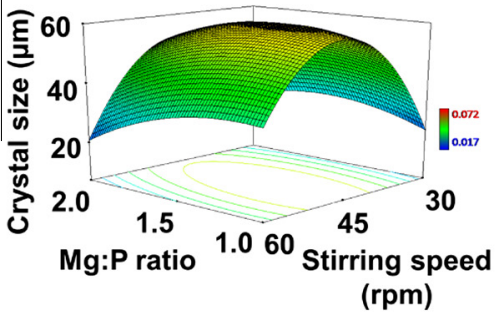

C

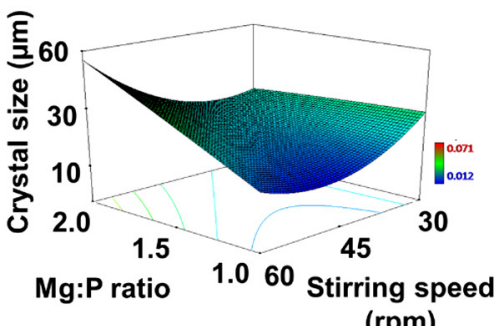

Aa

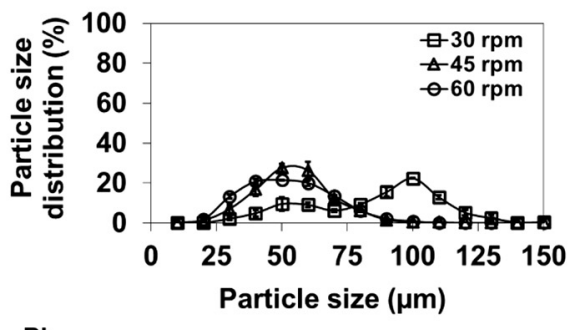

$\mathrm{Bb}$

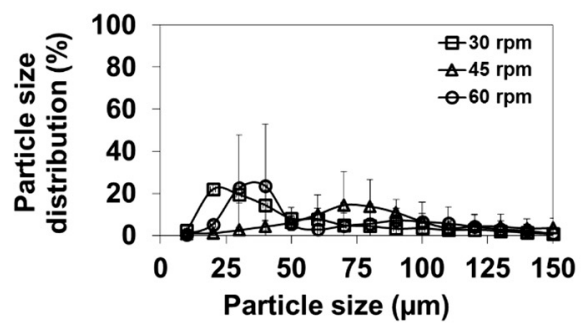

Cc

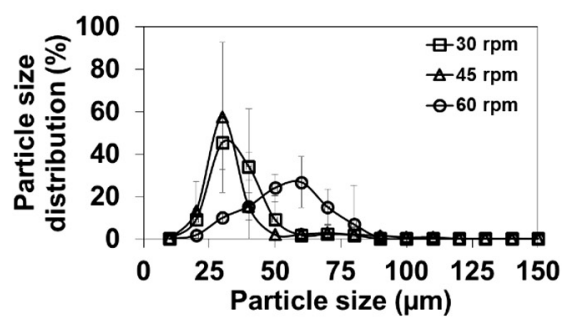

Fig. 2. Graphs showing the effect of $\mathrm{Mg}: \mathrm{P}$ ratio and stirring speed on crystal size (left) and particle size distribution (right) with (A) $\mathrm{MgO}(\mathrm{B}) \mathrm{MgCl}_{2}$ and $(\mathrm{C}) \mathrm{Mg}(\mathrm{OH})_{2}$ as $\mathrm{Mg}^{2+}$ sources.

Table 4

ANOVA analysis for the effect of Mg:P ratio and stirring speed on crystal size.

\begin{tabular}{llll}
\hline & \multicolumn{2}{l}{ Prob $>\mathrm{F}$} & \\
\cline { 2 - 4 } & $\mathrm{MgO}^{\mathrm{a}}$ & $\mathrm{MgCl}_{2}{ }^{\mathrm{b}}$ & $\mathrm{Mg}(\mathrm{OH})_{2}{ }^{\mathrm{c}}$ \\
\hline Model & $<0.0001$ & 0.0260 & 0.0111 \\
$\mathrm{~A}:$ Mg:P ratio & $0.5051(-)$ & $0.3505(+)$ & $0.0043(-)$ \\
$\mathrm{B}:$ Stirring speed & $0.1265(-)$ & $0.0014(+)$ & $0.0229(-)$ \\
$\mathrm{AB}$ & $0.5255(+)$ & $0.4227(-)$ & $0.0111(+)$ \\
$\mathrm{A}^{2}$ & $0.9311(+)$ & $0.4326(-)$ & $0.9379(-)$ \\
$\mathrm{B}^{2}$ & $0.0242(+)$ & $0.0012(-)$ & $0.0268(+)$ \\
\hline
\end{tabular}

a $\mathrm{SD}=0.011, R^{2}=0.872, R^{2} \mathrm{adj} .=0.823, \mathrm{AP}=10.097, \mathrm{CV}=17.95 \%$.

b $\mathrm{SD}=0.013, R^{2}=0.645, R^{2}$ adj. $=0.483, \mathrm{AP}=5.107, \mathrm{CV}=31.81 \%$,

c $\mathrm{SD}=8.76 \mathrm{E}-3, R^{2}=0.701, R^{2} \mathrm{adj} .=0.565, \mathrm{AP}=8.027, \mathrm{CV}=27.43 \%$.

not significantly affected by the stirring speeds tested (50$120 \mathrm{rpm}$ ) and obtained crystals with around $50 \mu \mathrm{m}$ using the same $\mathrm{Mg}^{2+}$ source $\left(\mathrm{MgCl}_{2}\right)$ and $50 \mathrm{rpm}$.

The quadratic model achieved for $\mathrm{Mg}(\mathrm{OH})_{2}$ indicated that the significant model terms were $\mathrm{A}, \mathrm{B}, \mathrm{AB}$ and $\mathrm{B}^{2}$ showing that both variables had an important effect on crystal size (Table 4). The crystals obtained with this $\mathrm{Mg}^{2+}$ source were smaller than the obtained with the other $\mathrm{Mg}^{2+}$ sources. Approximately 50\% of the crystals developed with 30 and $45 \mathrm{rpm}$ had around $30 \mu \mathrm{m}$. Crystals with around $60 \mu \mathrm{m}$, were achieved in the $60 \mathrm{rpm}$ experiments (Fig. 2Cc).

The effect of each variable on crystal size was described for $\mathrm{MgO}$ $(F$-value $=4.39), \mathrm{MgCl}_{2}(F$-value $=3.99)$ and $\mathrm{Mg}(\mathrm{OH})_{2} \quad(F$-value $=$ 5.16) by following quadratic model equations:

$$
\begin{aligned}
\operatorname{Crystal}_{\text {size }}(\mu \mathrm{m})= & 0.28-0.02 \mathrm{~A}-7.67 \mathrm{E}-3 \mathrm{~B}+3.33 \mathrm{E}-4 \mathrm{AB} \\
& +1.83 \mathrm{E}-3 \mathrm{~A}^{2}+5.87 \mathrm{E}-5 \mathrm{~B}^{2} \\
\operatorname{Crystal}_{\text {size }}(\mu \mathrm{m})= & -0.28+0.09 \mathrm{~A}+0.01 \mathrm{~B}-6.26 \mathrm{E}-4 \mathrm{AB} \\
& -0.02 \mathrm{~A}^{2}-1.26 \mathrm{~B}^{2} \\
\operatorname{Crystal}_{\text {size }}(\mu \mathrm{m})= & 0.18-0.04 \mathrm{~A}-6.49 \mathrm{E}-3 \mathrm{~B}+1.39 \mathrm{E}-3 \mathrm{AB} \\
& -1.41 \mathrm{E}-3 \mathrm{~A}^{2}+5.12 \mathrm{E}-5 \mathrm{~B}^{2}
\end{aligned}
$$

3.2.2. Characterization and identification of crystals - XRD and SEMEDS

Microscopic image analysis showed that the crystals shape was non-uniform depending of the $\mathrm{Mg}^{2+}$ source (Fig. 3). Usual crystal morphologies include coffin-like [37], needle-like [16], x-shape [39] and rod shape [20]. Using MgO, the obtained precipitate exhibited an irregular shape, and some crystals with a typical xshape. Using $\mathrm{MgCl}_{2}$ and $\mathrm{Mg}(\mathrm{OH})_{2}$, the morphology of the precipitated crystals were similar showing the typical prismatic pattern of the struvite crystals. Korchef et al. [40] and Münch and Barr [34] reported similar crystals shape using $\mathrm{MgCl}_{2}$ and $\mathrm{Mg}(\mathrm{OH})_{2}$ as $\mathrm{Mg}^{2+}$ sources.

Samples of the collected precipitate obtained after P removal with Mg:P of 1.5:1 and $45 \mathrm{rpm}$ for each $\mathrm{Mg}^{2+}$ source were selected for crystals characterization. The content of struvite in the precipitates was confirmed by SEM, SEM-EDS and XRD techniques. SEMEDS analyses of the crystals are shown in Fig. 3. Chemical element composition showed the presence of $\mathrm{Mg}, \mathrm{P}, \mathrm{N}$ and $\mathrm{O}$ on the crystals 

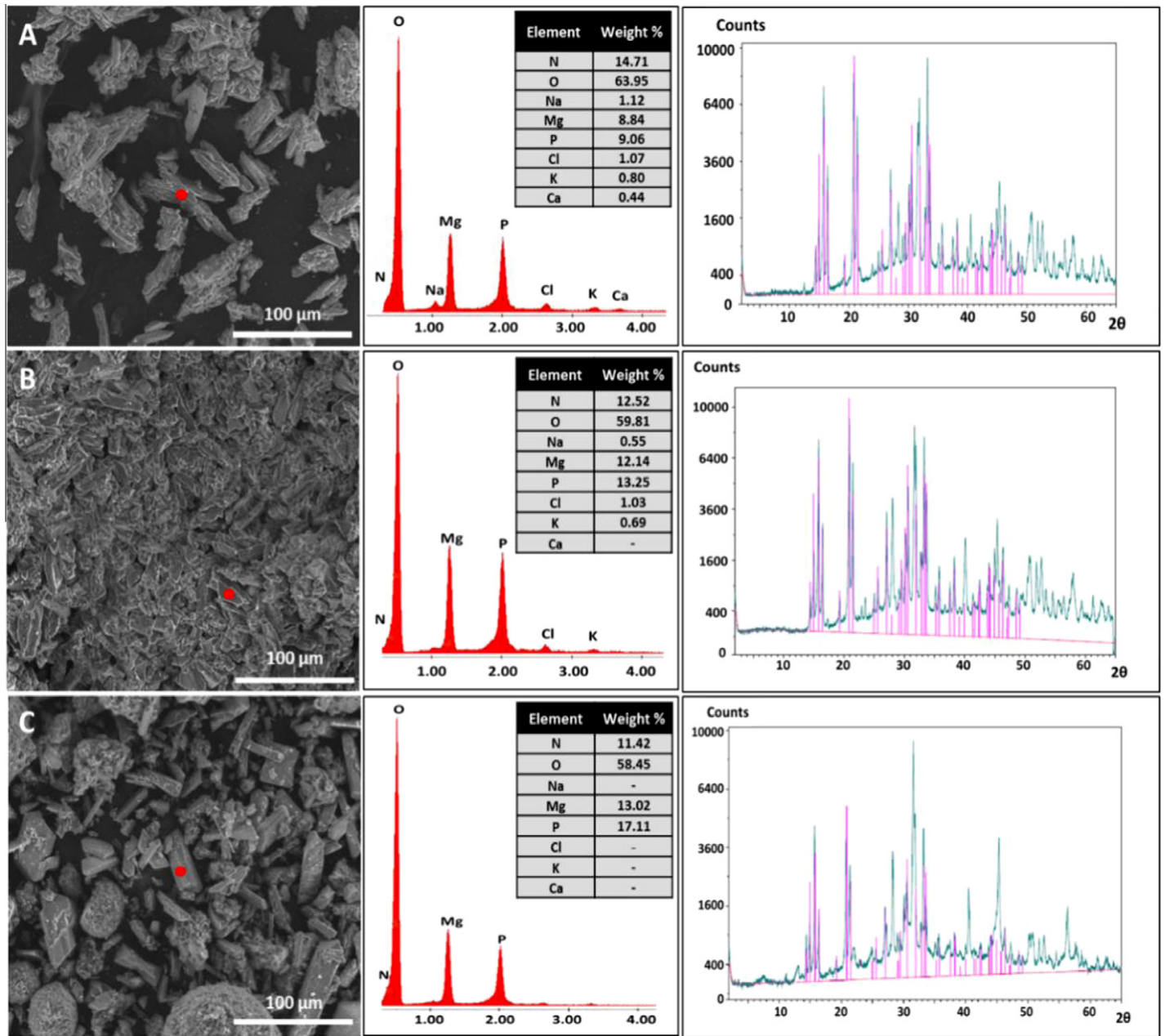

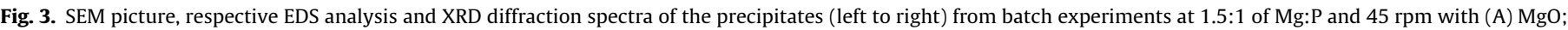

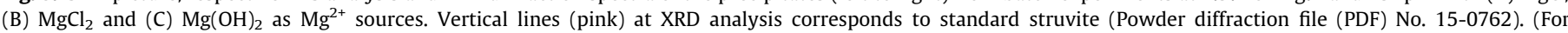
interpretation of the references to color in this figure legend, the reader is referred to the web version of this article.)

precipitated with three different $\mathrm{Mg}^{2+}$ sources, indicating that struvite was obtained with this process. The XRD patterns supports that the precipitates formed were a mixture of struvite with amorphous products. The prominent peaks of the precipitate matched very well with the standard model for struvite but a broad hump on the baseline was observed.

According to the SEM images, when $\mathrm{MgO}$ or $\mathrm{MgCl}_{2}$ were added, crystals of struvite were covered by other small amorphous precipitates (Fig. 3A and B), whereas, with $\mathrm{Mg}(\mathrm{OH})_{2}$, two different types of precipitates could be observed (Fig. $3 \mathrm{C}$ ).

\subsection{Economic overview}

$P$ recovery by struvite precipitation is a promising and feasible process not only in terms of environmental benefits [41] but also from an economic point of view [42]. P recovery from urine has the potential to greatly reduce $P$ loadings in wastewater treatment plants. Mihelcic et al. [11] reported that $P$ available from urine could account for $22 \%$ of the total global phosphorus demand. The economic viability of struvite precipitation includes not only the costs of the urine separation implementation and the effects on wastewater treatment process but also the costs of precipitation process and the economic value added of struvite.

On the other hand, several studies reported that the efficiency of municipal wastewater treatment plants has been affected by precipitates, namely struvite, formed in the stench traps and pipes due to the high phosphate concentration in wastewater [21,22,37]. This may lead to an increase of operating and maintenance costs for cleaning unwanted struvite formed in pipes. Whilst struvite is unwanted in municipal wastewater treatment facilities if precipitation is controlled and cost-effective, struvite might have potential as fertilizer [43].

The costs related to the struvite production have been reported by several studies as highly dependent of the $\mathrm{P}$ concentration. According to Dockhorn [44] the fixed costs (e.g. investment, labor and energy) decrease with $\mathrm{P}$ concentration, whereas the variable cost mainly related to the $\mathrm{Mg}^{2+}$ source added, increase with $\mathrm{P}$ concentration. In our case, considering the initial P concentration, it is possible to observe that the cost of the $\mathrm{Mg}^{2+}$ sources contribute up to $70 \%$ of overall production costs. Waste products containing $\mathrm{Mg}$ such as bittern [45] and wood ash [46] are less expensive Mg sources and can be an interesting alternative to produce Mg salts, thus saving costs. However, due to the heterogeneous, composition, a reliable product is not always guaranteed and the marketability of the struvite may not be possible. For example, Sakthivel et al. [46] reported that wood ash is not a very suitable precipitant for struvite production because the precipitate has a low phosphorus content and can contain high concentrations of heavy metals. Therefore, due to the high influence of chemical's price in $\mathrm{P}$ recovery economic feasibility, cost savings may be achieved through the choice of an appropriate Mg source as a struvite precipitant. The calculated input costs for producing struvite 
Table 5

Estimated struvite production costs using industrial grade magnesium salts.

\begin{tabular}{lllll}
\hline & & $\mathrm{MgO}$ & $\mathrm{MgCl}_{2}$ & $\mathrm{Mg}(\mathrm{OH})_{2}$ \\
\hline Chemical formula & & $\mathrm{MgO}$ & $\mathrm{MgCl}_{2} \cdot 6 \mathrm{H}_{2} \mathrm{O}$ & $\mathrm{Mg}(\mathrm{OH})_{2}$ \\
Product price & $€^{\mathrm{a}}$ & 29.40 & 5.35 & 12.12 \\
Magnesium content & $\mathrm{g} \mathrm{kg}^{-1}$ & 534 & 119 & 407 \\
Mg:P ratio & & $2: 1$ & $2: 1$ & $2: 1$ \\
Required input & $\mathrm{kg} \mathrm{kg}_{\text {struvite }}^{-1}$ & 0.16 & 0.86 & 0.24 \\
Input cost & $€ \mathrm{~kg}_{\text {struvite }}$ & 4.62 & 4.62 & 2.82 \\
\hline
\end{tabular}

a Price quoted by VWR International, for a $25 \mathrm{~kg}$ bag of technical grade material (January 2016).

based on the market prices of different $\mathrm{Mg}$ sources is presented in Table 5. A comparative analysis shows that the cost of using $\mathrm{MgO}$ or $\mathrm{MgCl}_{2}$ is similar. However, $\mathrm{MgO}$ presents some advantages due to the high $\mathrm{Mg}$ content that contributes for a less quantity of chemical added simplifying the logistic and reducing the transportation costs. Moreover, basic character in $\mathrm{pH}$ adjustment of $\mathrm{MgO}$ allows to achieve the optimal $\mathrm{pH}$ value (8.5) for struvite precipitation without any alkali addition.

\section{Conclusions}

A central composite face-centred design (CCF), using a response surface methodology allowed to optimize struvite precipitation from undiluted human urine. Statistical analysis revealed that the maximum $\mathrm{P}$ recovery was achieved using $\mathrm{MgO}$ as $\mathrm{Mg}^{2+}$ source at 2:1 molar ratio and a stirring speed of $30 \mathrm{rpm}$. 99\% recovery of $\mathrm{P}$ and simultaneously formation of struvite crystals of $50-100 \mu \mathrm{m}$ size were obtained. XRD and SEM EDS analysis revealed that the precipitate formed was a mixture of struvite with amorphous products.

\section{Acknowledgements}

This project has received funding from the European Union's Seventh Programme for research, technological development and demonstration under grant agreement No. 308535. The authors also acknowledge the Portuguese Foundation for Science and Technology (FCT) under the scope of the strategic funding of UID/BIO/04469/2013 unit, COMPETE 2020 (POCI-01-0145-FEDER006684) and the project RECI/BBB-EBI/0179/2012 (FCOMP-010124-FEDER-027462).

\section{Appendix A. Supplementary data}

Supplementary data associated with this article can be found, in the online version, at http://dx.doi.org/10.1016/j.cej.2016.03.148.

\section{References}

[1] U.S. Geological Survey, Mineral commodity summaries 2013, U.S. Geol. Surv. 198 (2013).

[2] D. Cordell, S. White, Life's bottleneck: sustaining the world's phosphorus for a food secure future, Annu. Rev. Environ. Resour. 39 (2014) 161-188.

[3] D. Cordell, J.-O. Drangert, S. White, The story of phosphorus: global food security and food for thought, Global Environ. Change 19 (2009) 292-305.

[4] J. Wang, J.G. Burken, X.J. Zhang, R. Surampalli, Engineered struvite precipitation: impacts of component-ion molar ratios and $\mathrm{pH}, \mathrm{J}$. Environ. Eng. 1433-1440 (2005).

[5] J.A. O'Neal, T.H. Boyer, Phosphate recovery using hybrid anion exchange: applications to source-separated urine and combined wastewater streams, Water Res. 47 (2013) 5003-5017.

[6] C. Santoro, I. Ieropoulos, J. Greenman, P. Cristiani, T. Vadas, A. Mackay, et al., Power generation and contaminant removal in single chamber microbial fuel cells (SCMFCs) treating human urine, Int. J. Hydrogen Energy 38 (2013) 1154311551.

[7] A. Hug, K.M. Udert, Struvite precipitation from urine with electrochemical magnesium dosage, Water Res. 47 (2013) 289-299.
[8] G.-L. Zang, G.-P. Sheng, W.-W. Li, Z.-H. Tong, R.J. Zeng, C. Shi, et al., Nutrient removal and energy production in a urine treatment process using magnesium ammonium phosphate precipitation and a microbial fuel cell technique, Phys. Chem. Chem. Phys. 14 (2012) 1978-1984.

[9] M. Maurer, W. Pronk, T.A. Larsen, Treatment processes for source-separated urine, Water Res. 40 (2006) 3151-3166.

[10] P. Kuntke, K.M. Smiech, H. Bruning, G. Zeeman, M. Saakes, T.H.J.A. Sleutels et al., Ammonium recovery and energy production from urine by a microbial fuel cell, Water Res. 46 (2012) 2627-2636.

[11] J.R. Mihelcic, L.M. Fry, R. Shaw, Global potential of phosphorus recovery from human urine and feces, Chemosphere 84 (2011) 832-839.

[12] S. Antonini, S. Paris, T. Eichert, J. Clemens, Nitrogen and phosphorus recovery from human urine by struvite precipitation and air stripping in Vietnam, CLEAN - Soil Air Water 39 (2011) 1099-1104.

[13] B. Etter, E. Tilley, R. Khadka, K.M. Udert, Low-cost struvite production using source-separated urine in Nepal, Water Res. 45 (2011) 852-862.

[14] M. Krähenbühl, B. Etter, K.M. Udert, Pretreated magnesite as a source of lowcost magnesium for producing struvite from urine in Nepal, Sci. Total Environ. 542 (2016) 1155-1161.

[15] P. Ledezma, P. Kuntke, C.J.N. Buisman, J. Keller, S. Freguia, Source-separated urine opens golden opportunities for microbial electrochemical technologies, Trends Biotechnol. 33 (2015) 214-220.

[16] J.A. Wilsenach, C.A.H. Schuurbiers, M.C.M. van Loosdrecht, Phosphate and potassium recovery from source separated urine through struvite precipitation, Water Res. 41 (2007) 458-466.

[17] M. Ronteltap, M. Maurer, W. Gujer, Struvite precipitation thermodynamics in source-separated urine, Water Res. 41 (2007) 977-984.

[18] E. Tilley, J. Atwater, D. Mavinic, Recovery of struvite from stored human urine Environ. Technol. 29 (2008) 797-806.

[19] J. Lienert, T.A. Larsen, High acceptance of urine source separation in seven European countries: a review, Environ. Sci. Technol. 44 (2010) 556-566.

[20] E. Desmidt, K. Ghyselbrecht, A. Monballiu, K. Rabaey, W. Verstraete, B.D. Meesschaert, Factors influencing urease driven struvite precipitation, Sep. Purif. Technol. 110 (2013) 150-157.

[21] K.M. Udert, T.A. Larsen, M. Biebow, W. Gujer, Urea hydrolysis and precipitation dynamics in a urine-collecting system, Water Res. 37 (2003) 2571-2582.

[22] C.M. Mehta, D. Batstone, Nucleation and growth kinetics of struvite crystallization, Water Res. 47 (2013) 2890-2900.

[23] R. Yu, H. Ren, Y. Wang, L. Ding, J. Geng, K. Xu, et al., A kinetic study of struvite precipitation recycling technology with $\mathrm{NaOH} / \mathrm{Mg}(\mathrm{OH})_{2}$ addition, Bioresour. Technol. 143 (2013) 519-524.

[24] P.L. Bishop, Enhancing struvite crystallization from anaerobic supernatant, J. Environ. Eng. Sci. 3 (2004) 21-29.

[25] M.S. Rahaman, N. Ellis, D.S. Mavinic, Effects of various process parameters on struvite precipitation, Water Sci. Technol. 57 (2008) 647-654.

[26] A. Qureshi, K.V. Lo, P.H. Liao, Microwave treatment and struvite recovery potential of dairy manure, J. Environ. Sci. Health B 43 (2008) 350-357.

[27] Y. Song, P. Yuan, B. Zheng, J. Peng, F. Yuan, Y. Gao, Nutrients removal and recovery by crystallization of magnesium ammonium phosphate from synthetic swine wastewater, Chemosphere 69 (2007) 319-324.

[28] J. Wang, J.G. Burken, X. Zhang, Effect of seeding materials and mixing strength on struvite precipitation, Water Environ. Res. 78 (2006) 125-132.

[29] S. Ishak, A. Malakahmad, Optimization of Fenton process for refinery wastewater biodegradability augmentation, Korean J. Chem. Eng. 30 (2013) 1083-1090.

[30] APHA, AWWA, WPCF, Standard Methods for the Examination of Water and Wastewater, 17th ed., 1998. Washington, DC.

[31] Z. Liu, Q. Zhao, K. Wang, D. Lee, W. Qiu, J. Wang, Urea hydrolysis and recovery of nitrogen and phosphorus as MAP from stale human urine, J. Environ. Sci. 20 (2008) 1018-1024.

[32] X. Liu, Z. Hu, C. Zhu, G. Wen, X. Meng, J. Lu, Effect of contact to the atmosphere and dilution on phosphorus recovery from human urine through struvite formation, Environ. Technol. 35 (2013) 271-277.

[33] A. Capdevielle, E. Sýkorová, B. Biscans, F. Béline, M.-L. Daumer, Optimization of struvite precipitation in synthetic biologically treated swine wastewaterdetermination of the optimal process parameters, J. Hazard. Mater. 244-245 (2013) 357-369.

[34] E. Münch, K. Barr, Controlled struvite crystallisation for removing phosphorus from anaerobic digester sidestreams, Water Res. 35 (2001) 151-159.

[35] A. Adnan, D.S. Mavinic, F.A. Koch, Pilot-scale study of phosphorus recovery through struvite crystallization - examining the process feasibility, J. Environ. Eng. 2 (2003) 315-324.

[36] B.K.N. Ohlinger, S. Member, T.M. Young, A. Member, E.D. Schroeder, Kinetics effects on preferential struvite accumulation in wastewater, J. Environ. Eng. 125 (1999) 730-737.

[37] J.D. Doyle, S.A. Parsons, Struvite formation, control and recovery, Water Res. 36 (2002) 3925-3940.

[38] E. Ariyanto, T.K. Sen, H.M. Ang, The influence of various physico-chemical process parameters on kinetics and growth mechanism of struvite crystallisation, Adv. Powder Technol. 25 (2014) 682-694.

[39] M. Ronteltap, M. Maurer, R. Hausherr, W. Gujer, Struvite precipitation from urine - influencing factors on particle size, Water Res. 44 (2010) 2038-2046.

[40] A. Korchef, H. Saidou, M. Ben Amor, Phosphate recovery through struvite precipitation by $\mathrm{CO}_{2}$ removal: effect of magnesium, phosphate and ammonium concentrations, J. Hazard. Mater. 186 (2011) 602-613. 
41] L.E. De-Bashan, Y. Bashan, Recent advances in removing phosphorus from wastewater and its future use as fertilizer (1997-2003), Water Res. 38 (2004) 4222-4246.

[42] P. Schneider, J.E. Johnson, L. Shu, P. Schneider, V. Jegatheesan, An economica evaluation of phosphorus as struvite from digester supernatant, Bioresour. Technol. 97 (2006) 2211-2216.

[43] K. Gell, F.J. D. Ruijter, P. Kuntke, M. De Graaff, A.L. Smit, Safety and effectiveness of struvite from black water and urine as a phosphorus fertilizer, J. Agric. Sci. 3 (2011) 67-80.
[44] T. Dockhorn, About the economy of phosphorus recovery, in: A. Ken, D. Mavinic, F. Kock (Eds.), Int. Conf. Nutr. Recover. from Wastewater Streams, first, IWA Publishing, London, 2009, pp. 145-158.

[45] Z.L. Ye, S.H. Chen, M. Lu, J.W. Shi, L.F. Lin, S.M. Wang, Recovering phosphorus as struvite from the digested swine wastewater with bittern as a magnesium source, Water Sci. Technol. 64 (2011) 334-340.

[46] S.R. Sakthivel, E. Tilley, K.M. Udert, Wood ash as a magnesium source for phosphorus recovery from source-separated urine, Sci. Total Environ. 419 (2012) 68-75. 